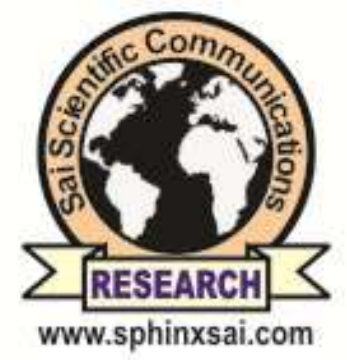

\author{
Chemiech \\ International Journal of ChemTech Research \\ CODEN (USA): IJCRGG, ISSN: 0974-4290, ISSN(Online):2455-9555 \\ Vol.13 No.03, pp 120-124, 2020
}

\title{
Child Rescue from Bore Well
}

\author{
S.Magibalan ${ }^{1 *}$, A.Mohanraj $^{2}$, S.Navin $^{3}$, N.Nirmal kumar $^{4}$, C.V.Pranavsuresh ${ }^{5}$ \\ ${ }^{1}$ Assistant Professor, ${ }^{2,3,4,5}$ UG Student, \\ ${ }^{1-5}$ Department of Mechanical engineering, K.S.R College of engineering, Tiruchengode, \\ Tamilnadu, India.
}

\begin{abstract}
This paper is based on rescue the child which fell down into the bore well hole. The low agechildren were playing near the open bore well may fall into the bore well. We consider the children at this age for the design of this project. The bore well hole in which the child would fall is at the major diameter of 12 inch. Nowadays, the rescuing operation is accomplished by the method of dig a parallel drill close to the bore well with the same depth of the child and makes a passage that interfaces with the both wells. It takes about many hours to burrow the new well. To overcome this concern, a gripper to hold the child and using stand we lift the child from bore well using simple mechanical equipment's to lift the child.
\end{abstract}

Keywords : Camera, DC Motor, Gripper, Bore well, Rope and Pulley Drive.

\section{Introduction}

In past few years, children get trapped into the bore well hole which is left uncovered. The rescue method to make the child to bring out of the bore well is long and complicated. To avoid this, there have been several rescue robots design available currently. Scarcity of water is one of the most important problems in India. The ground water level is decreasing day by day so many peoples are affected. Bore wells are constructed to overcome water scarcity. These bore wells are left opened after finding that ground water is not abundant in that place. Small children without noticing the bore well fell inside and get trapped. Currently, we have conventional method to safeguard the child but modern methods has to be found to avoid such accidents. In most cases an alternate pit will be taken across the actual hole then a side path will be dug which is very nearer to reach the baby. But this method of saving the child is a time taking and more risky process. Injuries may happen to the child inside the bore well.

S.Magibalan et al/International Journal of ChemTech Research, 2020,13(3): 120-124.

DOI= http://dx.doi.org/10.20902/IJCTR.2019.130308 
The government of India has taken many steps in this regards and every attempt has got some way to improve upon the system. The device was proposed to rescue a child from the bore well, this device consists of gripper which will evacuate the child from the well. The main concern with this implementation technique is that, the arm developed to grasp the child is mechanical and it is very difficult to position the robotic arm irrespective to the position of the victim also it may harm the child while holding. Then a robotic machine was proposed to rescue a child from the bore well, this device consists of robotic arm which will evacuate the child from the well.

\section{Literature Review}

Pal winder et.al proposed the rescue operation of child from bore well with a human. They uses a wheeled leg mechanism, it's taken into the bore well and legs are circumferentially and symmetrical into 1200 apart. The robot will be adjust itself according to bore well dimensions. The robot consists a gear motor, power supply, switch pad and camera. The child position is visualize using USB camera and monitored on computer. The PIC 16F877A microcontroller connecter with 16*2 LCD and LM35 temperature sensor and displayed on LCD monitor.

Arthika et.al proposed the mechanism of life saving of child from bore well. They used a temperature sensor to detect the child temperature and detect the level of gases in bore well using gas sensor in the certain region. The ARM compression and expansion technique used for up and down motion. The robotic arm is used for a pick and place the child from well. It provides safest method and less time taken. The drawback is using gripper it's very difficult to lift the child safely.

Gopinath et.al proposed in a paper, recovery of child from bore well without a danger. They used ARM8 processor interface. Having of camera along with LED light to visualize the child and operate the system by control unit. The child head can hold using vacuum cup as required to child position. Once child picked perfectly by robot, the BLDC motor will take out from bore well. The zigbee is used for transferring the data with the keil simulation software. Then lift the child from well without injury.

Mathankumar and Manonmani proposed a method of child reuse from bore well. The child are fell into the bore well. They using morphological chart and various design formulated. A components of digital integrated camera, rope and pulley drive, digital oxygen power supply and strain measuring pressure. After fixing of gripper the grasping process takes by actuating a piston cylinder with directional control value. The rope is pulled up using motor and taken off from the ground level and rescued safely.

Saran et.al proposed, now a days children's are fell into uncovered bore wells and trapped in. They design a robot structure haves microcontroller, power supply, gear motor, switch pad, oxygen concenter and camera. In TV monitor the condition of trapped child can be monitored by CCTV camera. For an extra safety introduced a safety balloon is provided. Once lifting rod reaches a safe position under the children, an air compressor pumps air to the bladder towards the rod. The bladder provides a secure seating to the child. The lifting rod is taken out from the bore well using rope or chain.

Sumitpandey et.al proposed, rescue infants fall into the bore well. Now a day's rescue operation takes place by digging a parallel pit, it takes more than a day and not getting a perfect result. The highest point of the project is taken a child before its reaching high depth in bore well, which is communication by using infra-red signal from sensor. The signal comes from IR obstructing object stops and buzzer sound starts and also alert in mobile phone. The various risks factors are minimized in the system.

Sumalatha et.al proposed present scenario of child death in bore wells. The robot is operated by zigbee technology. Here they proposed an Arduino based system for child rescue from bore well. Below reference table the review. 
Incident of Trapped Children in Borewell

\begin{tabular}{|c|c|c|c|c|c|c|}
\hline S.No & Name of Child & Age & Place of Incident & $\begin{array}{l}\text { Period of } \\
\text { Incident }\end{array}$ & \begin{tabular}{|l|} 
Rescue duration \\
(Hrs.)
\end{tabular} & $\begin{array}{l}\text { Status of } \\
\text { life }\end{array}$ \\
\hline 1. & Bhima & 5 & Rajasthan & 05 Dec 2019 & 8 & Live \\
\hline 2. & Shivani & 5 & Haryana & 18 Nov2019 & 18 & Died \\
\hline 3. & Surjithwilson & 2 & Trichy & 28 Oct2019 & 72 & Died \\
\hline 4. & Pradeep & 4 & Punjab & 14 Jun2019 & 52 & Died \\
\hline 5. & Fatehvir & 2 & Punjab & 11 Jun2019 & 110 & Died \\
\hline 6. & Gautamsahni & 20 & Bihar & 31 May2019 & 90 & Died \\
\hline 7. & Ajaypaul & 18 & Bihar & 31 May2019 & 90 & Died \\
\hline 8. & Seema & 4 & Jodhpur & 21 May2019 & 14 & Died \\
\hline 9. & Nadim & 2 & Haryana & Mar2019 & 10 & Live \\
\hline 10. & Ravipanditbhil & 6 & Pune & 21 feb2019 & 16 & Live \\
\hline 11. & Sanno & 3 & Bihar & 01 Aug2018 & 30 & Live \\
\hline 12. & Chandrasekhar & 2 & Vijayawada & 16 Aug2018 & 11 & Live \\
\hline 13. & Sana & 3 & Rajasthan & Aug 2018 & 28 & Live \\
\hline 14. & Veena & 2 & Hyderabad & Jun 2017 & 28 & Died \\
\hline 15. & Chinnari & 1 & Hyderabad & 22 jun2017 & 58 & Died \\
\hline 16. & Kaveri & 6 & Belagavi & 25 Apr2017 & 54 & Died \\
\hline 17. & Girl* & 2 & Jodpur & 01 Jul2016 & 48 & Died \\
\hline 18. & Sunil & 4 & Pune & 02 May2016 & 30 & Live \\
\hline 19. & Girl* & 4 & Arani & 20 Jun2014 & 64 & Died \\
\hline 20. & Akshata & 4 & Bijapur & 18 jun2014 & 48 & Died \\
\hline 21. & Boy* & 3 & Tirunelveli & 14 Apr2014 & 8 & Live \\
\hline 22. & Radheyshyam & 2 & Rajasthan & 07 Jan2014 & 32 & Died \\
\hline 23. & Muthulakshmi & 7 & Karur & 28 Apr2013 & 14 & Live \\
\hline 24. & Suchin & 1 & Chennai & 17 Jul2012 & 16 & Live \\
\hline 25. & Sumit & 5 & Haryana & 06 Jul2012 & 38 & Died \\
\hline 26. & Boy* & 4 & Bhilwara & Jan 2010 & 22 & Died \\
\hline 27. & Mahi & 5 & Gurgaon & 22 Jan 2012 & 83 & Died \\
\hline 28. & Prasath & 2 & Warangal & 18 Jan2010 & 24 & Died \\
\hline 29. & Anuj & 4 & Davsa & June 2009 & 20 & Live \\
\hline 30. & Suraj & 5 & Jaipur & July 2007 & 55 & Died \\
\hline 31. & Prince & 5 & Haryana & June 2006 & 48 & Live \\
\hline 32. & Tamil Mani & 5 & Chennai & 01 Sep 2001 & 58 & Died \\
\hline 33. & Jassica & 2 & Texas & 14 Oct 1987 & 22 & Live \\
\hline 34. & Kathy Fiscus & 3 & California & 08 April 1949 & 100 & Died \\
\hline 35. & Alfredo & 6 & Italy & June 1981 & 260 & Died \\
\hline
\end{tabular}




\section{Design Layout}

This device have a 4 M.S rods arranged in a rectangular manner which consist a large dia pulley. The one end is connected with a rod through pulley at the other end. The other end consist of a hanging disc motor which is rotatable with the help of dc motor. This disc also consists of a clamp arrangement which consists of a pair of claws. This disc also consists of a stand which is in a deflated form when it reaches the child it goes down the child then open the in vertical position to horizontal position. The disc also consists of a camera through which the position of child is notices in the display.

\section{Working}

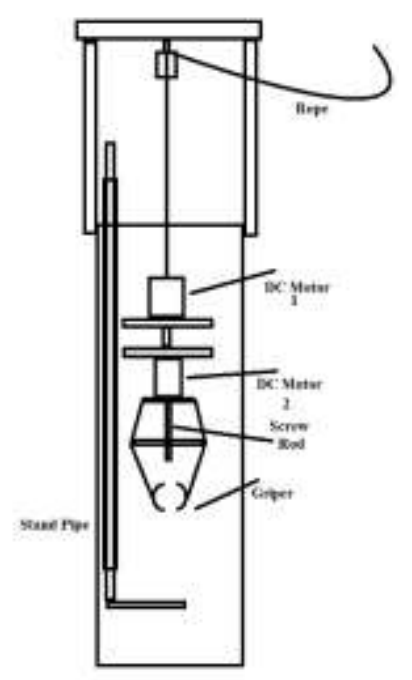

The working mechanism of this projected system is a process of pick and place mechanism, the safety method is dealing with a child life. Setup of the system having a metal supporting stand with pulley and its places above the bore well. Then connects the rope to the pulley and the device is sent into the bore well. As the device reaches the child his position can be visible on the monitor with the help of wireless camera along with the device. Based on the position of the child the device will be rotate with the help of camera and DC motor. The device haves a gripper to hold the child hand after the grabbing the hand. Lowering another mechanism of vertical rod at end of that having a plate into the bore well.

When reaches the child slowly taken down to the child then using push lever at top of the rod, plate be open into horizontal positioned flat stand for child to lift, after ensuring the safety of the child pull the whole device setup slowly outwards from bore well.

\section{Conclusion}

In this paper, Developed a prototype to rescue children falling in to bore-wells, this implies a new design which placed sensor kept at top of bore-well hole which helps to sense the child if he falls inside. If the device senses the child the automatic moves downwards closure kept at around $3 \mathrm{ft}$ depth closes and prevents the children from breathing problems. In future, this paper can be taken to the product level as a project which is easily accessible and user friendly. In further development need to make it small size and cheap cost. In future, most of the units can be connected with embedded system along with the single board controller with change in new technology, then reducing a size of device. 


\section{Acknowledgement}

We take immense pleasure in expressing our sincere thanks to the management and Dr.balan, Assistant professor, KSR College of engineering, Tiruchengode, India for their kind support and encouragement.

\section{References}

1. SanketArunTalekar, SurajBhimraoKatkar, PoojaKumari, Rescue System for Borewell Accidents. International Journal of Recent Advances in Engineering \& Technology, Volume-3, Issue -2, 2015.

2. Monisha K, Mythilid C, Priya S.M , Anandha Prakash P, A Multifunctional System Based Rescue Robot Adapted For Borehole Accidents Controlled Using Arduino, International Journal of Innovative Research in Science, Engineering and Technology ,Vol. 7, Special Issue 2, March 2018.

3. ShivamBajpai, Abhinav Singh, Ravi Shankar Rai, Ashwani Sharma, C.K. Jha, Design and Fabrication of Bore Well Rescue Robot, International Journal of Engineering Science and Computing, Volume 7 Issue No.5 May 2017.

4. P. Suji, B. ShahinaFarhin, N. Sheikh ChandiniRamijha and G, Smart borewell Rescuing RobotIndo-Iranian Journal of Scientific Research (IIJSR), Volume 2, Issue 2, April-June 2018.

5. B.VenkataSathish Kumar, PuttuGowri , M.Tech, Vasireddy, Bore Well Rescue Robot, Iconic Research And Engineering Journals, Volume 1 Issue 4October 2017.

6. S.Gopinath, T.Devika, L.Manivannan, Dr.N.SuthanthiraVanitha, Rescue Child from Bore well using Embedded System, International Research Journal of Engineering and Technology, Volume: 02 Issue: 03 June 2015.

7. S. Prakash, K. Narmadha Devi, J.Naveetha, V.Vasanth,V.Vishnushree, Smart Bore Well Child Rescue System, International Research Journal of Engineering and Technology (IRJET), Volume: 04 Issue: 03 Mar 2017.

8. K.Arunkumar, K.S.Selvakumar, K.Sriguna, K.Subash, Borewell Rescue Robot, International Journal of Research in Mechanical Mechatronics and Automobile Engineering, Vol. 1, Issue 2, Sep, 2015.

9. N. Bourbakis and I. Papadakis-Ktistakis ATRC, "Design Ground Bio-inspired Micro-System Structure for Detecting Humans in disastrous region". Wright State University, Dayton, OH 45435 and Technical University of Crete, Greece.June, 2017.

10. Lawrence Danieal R, Vinolee R, RuhanBevi A, Design Of Robotic System To Rescue A Child Under Constrained Environment, International Journal of Innovative Research in Advanced Engineering (IJIRAE), Issue 03, Volume 6, March 2019.

11. Praveen Kumar Nayak, Shefali Saini, Maharishi Varsha Sharma, An Audit Paper on Bore well Rescue Robot International Journal of Engineering Research \& Technology (IJERT), Vol. 8 Issue 05, May-2019. 